\title{
EFFECTS OF PUROMYCIN, ACETOXYCYCLOHEXIMIDE AND ACTINOMYCIN D ON PROTEIN SYNTHESIS IN GOLDFISH BRAIN*
}

\author{
John J. Brink†, Roger E. Davis† and Bernard W. Agranoff \\ Department of Biological Chemistry and Mental Health Research Institute, \\ University of Michigan, Ann Arbor, Michigan
}

(Received 27 January 1966)

EXPERIMENTS in our laboratory have demonstrated that memory fixation of a shockavoidance task in the goldfish can be blocked by puromycin or acetoxycycloheximide (AXM) $\$$ when administered within 1 hr after training, but not at later times (AGRANOFF and Klinger, 1964; Davis, Bright and Agranoff, 1965; Agranoff, Davis and BRINK, 1965, 1966). The present studies report the effects of these compounds as well as actinomycin $\mathrm{D}$ on the incorporation of $\left[{ }^{3} \mathrm{H}\right]$ leucine into goldfish brain protein.

\section{MATERIALS AND METHODS}

Experimental animals. Goldfish (Carassius auratus) weighing 9-11 g were selected from weekly shipments of fish of 6-7 cm body length from Ozark Fisheries (Stoutland, Mo.). They were set out in individual 1.5 I. tanks $24 \mathrm{hr}$ before the start of an experiment and were not fed subsequently.

Reagents. Puromycin dihydrochloride (Nutritional Biochemicals Corp., Cleveland, Ohio) was dissolved at three concentrations, 5,9 and $17 \mathrm{mg} / \mathrm{ml} \mathrm{in} 0.15 \mathrm{M}-\mathrm{NaCl}$, which is isotonic with goldfish serum (Levine and Musallam, 1964). AXM was a gift of T. C. McBride, Chas. Pfizer and Co., Maywood, N. J., and was dissolved at a concentration of $10 \mu \mathrm{g} / \mathrm{ml}$ in $0.15 \mathrm{M}-\mathrm{NaCl}$. Actinomycin D, generously supplied by Merck, Sharpe, and Dohme Co., West Point, Pa., was prepared at a concentration of $0.2 \mathrm{mg} / \mathrm{ml}$ in $0.15 \mathrm{M}-\mathrm{NaCl}$. L- $\left[4,5-{ }^{3} \mathrm{H}\right]$ leucine hydrochloride in $0.01 \mathrm{~N}-\mathrm{HCl}(5 \mathrm{mc} / \mu \mathrm{mole}$, New England Nuclear Corp., Boston, Mass.) was neutralized with solid $\mathrm{NaHCO}_{3}$ before use. Puromycin was injected intracranially (IC) as described previously (AGRANOFF and KLINGER, 1964). The labelled leucine was injected intraperitoneally (IP) with a $1.2 \mathrm{~cm} 20$ gauge needle held at $45^{\circ}$ to the lateral surface of the goldfish about $0.7 \mathrm{~cm}$ above the cloacal orifice.

$\left[{ }^{3} \mathrm{H}\right]$ Leucine incorporation in brain protein. At specified times following injections, fish were removed from their individual tanks. The spinal cord was severed with a scissors just posterior to the cranium, and the brain was exposed by removing the top of the skull. It was removed with a narrow spatula, blotted on paper towelling, and transferred to liquid nitrogen in a Dewar flask. The entire procedure took about $15 \mathrm{sec}$. Frozen brains (generally a pool of 10) were weighed and homogenized in 5 parts v/w of water at $4^{\circ}$ in a Duall tissue grinder (Kontes Glass Co., Vineland, N.J.).

Protein was isolated by a modification of the method of ROBERTs and Morelos (1965). The aqueous brain homogenate was rapidly pipetted into an equal volume of $10 \%$ trichloroacetic acid with magnetic stirring. Following centrifugation of the finely divided protein suspension, the precipitate was resuspended in $10 \mathrm{vol}$. (v/w, wet weight of brain) of $10 \%$ trichloroacetic acid and heated at $80^{\circ}$ for $30 \mathrm{~min}$ with constant stirring. The precipitate obtained after centrifugation was washed twice with 5 vol. of $95 \%$ ethanol, twice with 5 vol. of ether, dried and weighed A 10-15 mg portion of the dry protein was dissolved with heating at about $80^{\circ}$ for $20 \mathrm{sec}$ in $0.5 \mathrm{ml}$ of $1 \mathrm{M}$-Hyamine hydroxide (Packard Instrument Co., Downers Grove, Ill.) in a counting vial and mixed with $10 \mathrm{ml}$ of toluene-POPOP-PPO scintillation counting solution. A $0.1 \mathrm{ml}$ portion of the supernatant fraction was diluted with $10 \mathrm{ml}$ of xylene-dioxane-Cellosolve solution (BruNo and CHristiAN, 1961). All samples were counted in a TriCarb liquid scintillation counter. Quenching corrections were made from a plot of quenching $v s$. channel ratios.

* This investigation was supported by grant No. GB 925 from the National Science Foundation.

$\uparrow$ Interdisciplinary training fellow under USPHS training grant No. 5T7-MH-7417.

+ Abbreviations used: AXM, acetoxycycloheximide; IC, intracranial; IP, intraperitoneal. 


\section{RESULTS}

Time course of $\left[{ }^{3} \mathrm{H}\right]$ leucine uptake into brain protein. Preliminary experiments indicated that IC injections gave greater incorporation of $\left[{ }^{3} \mathrm{H}\right]$ leucine into protein than IP injections. However, there was considerable variability in the amount of radioactive leucine incorporated by the IC route. When $\left[{ }^{3} \mathrm{H}\right]$ leucine was given IP, there was still considerable variation among individual fish. In subsequent experiments, ten fish brains were pooled for analysis (Table 1). When the ratio of radioactivity in protein to the radioactivity in the supernatant fraction was calculated, relatively small deviations from the means were observed. The ratio (disintegrations/min in protein/ disintegrations/min in supernatant fraction) $\times 100$ obtained for groups of five or ten fish, was used in further experiments as an index of the inhibition of protein synthesis caused by different drugs. A ratio half that found in animals which received no puromycin represents 50 per cent inhibition.

TABLE 1.-RADIOACTIVITY IN TRICHLOROACETIC ACID-SOLUBLE SUPERNATANT AND PROTEIN RESIDUE FRACTIONS OF GOLDFISH BRAINS

\begin{tabular}{|c|c|c|c|c|c|}
\hline & $p^{*}$ & $\mathbf{S}^{\dagger}$ & $(\mathbf{P} / \mathbf{S}) \times 100$ & $\begin{array}{l}\text { Body } \\
\text { weight } \\
\text { (g) }\end{array}$ & $\begin{array}{l}\text { Wet brain } \\
\text { weight } \\
\text { (mg) }\end{array}$ \\
\hline $\begin{array}{l}\text { Individual fish } \\
\text { Mean and S.D. } \\
\text { N }\end{array}$ & $23 \cdot 0 \underset{59}{ \pm} 15 \cdot 1$ & $160 \cdot 1 \underset{59}{ \pm} 79 \cdot 2$ & $\underset{59}{14 \cdot 01 \pm 4 \cdot 8}$ & $\begin{array}{c}9 \cdot 32 \pm 0.66 \\
40\end{array}$ & $\frac{81 \cdot 2 \pm 9 \cdot 7}{40}$ \\
\hline $\begin{array}{l}\text { Mean and S.D. } \\
\text { N }\end{array}$ & $22 \cdot 5 \pm \frac{6}{8} \cdot 3$ & $150 \cdot 3 \underset{8}{ \pm} 39.9$ & $\frac{15 \cdot 1}{8}$ & - & $86 \cdot 1 \pm 3.9$ \\
\hline
\end{tabular}

Goldfish were injected IP with $20 \mu \mathrm{C}$ of $\left[{ }^{2} \mathrm{H}\right]$ leucine and killed $30 \mathrm{~min}$ later. Brains were analysed individually or pooled in groups of 10 .

* $\mathbf{P}=$ disintegrations/min $\times 10^{-3}$ in protein/fish brain.

$+\mathrm{S}=$ disintegrations/min $\times 10^{-8}$ in trichloroacetic acid-soluble supernatant fraction/fish brain.

To establish a time course for leucine incorporation into brain following IP injections, each goldfish in a group of five injected with $20 \mu \mathrm{C}$ of $\left[{ }^{3} \mathrm{H}\right]$ leucine in a volume of $20 \mu \mathrm{l}$. A rapid incorporation of radioactivity into the supernatant fraction of brain was observed reaching a peak in about $1 \mathrm{hr}$ and declining over the next day (Fig. 1), while the radioactivity of protein was maximal in about $4 \mathrm{hr}$. During a $24 \mathrm{hr}$ interval, approximately 20 per cent of the injected tritium appeared in the water of the fish tanks. Uptake into both fractions appeared linear for $30 \mathrm{~min}$, and this interval was used for subsequent experiments.

Puromycin. Groups of ten fish were injected IC with $10 \mu \mathrm{l}$ of a solution containing 50,90 , or $170 \mu \mathrm{g}$ of puromycin. At varying intervals thereafter, each animal received $20 \mu \mathrm{C}$ of $\left[{ }^{3} \mathrm{H}\right]$ leucine IP. The animals were removed from the tanks and killed $30 \mathrm{~min}$ after the leucine injection, and the pooled brains analysed for radioactivity. The results (Table 2) show that with the three concentrations employed, puromycin rapidly depressed the incorporation of $\left[{ }^{3} \mathrm{H}\right]$ leucine into brain protein. The rate of recovery from this inhibition, however, decreased as the dose of puromycin was increased. Animals that were given 50 or $90 \mu \mathrm{g}$ of puromycin showed no significant inhibition by approximately $16 \mathrm{hr}$, while fish that received $170 \mu \mathrm{g}$ required about 2 days to return to normal. 
Effects on protein in goldfish brain

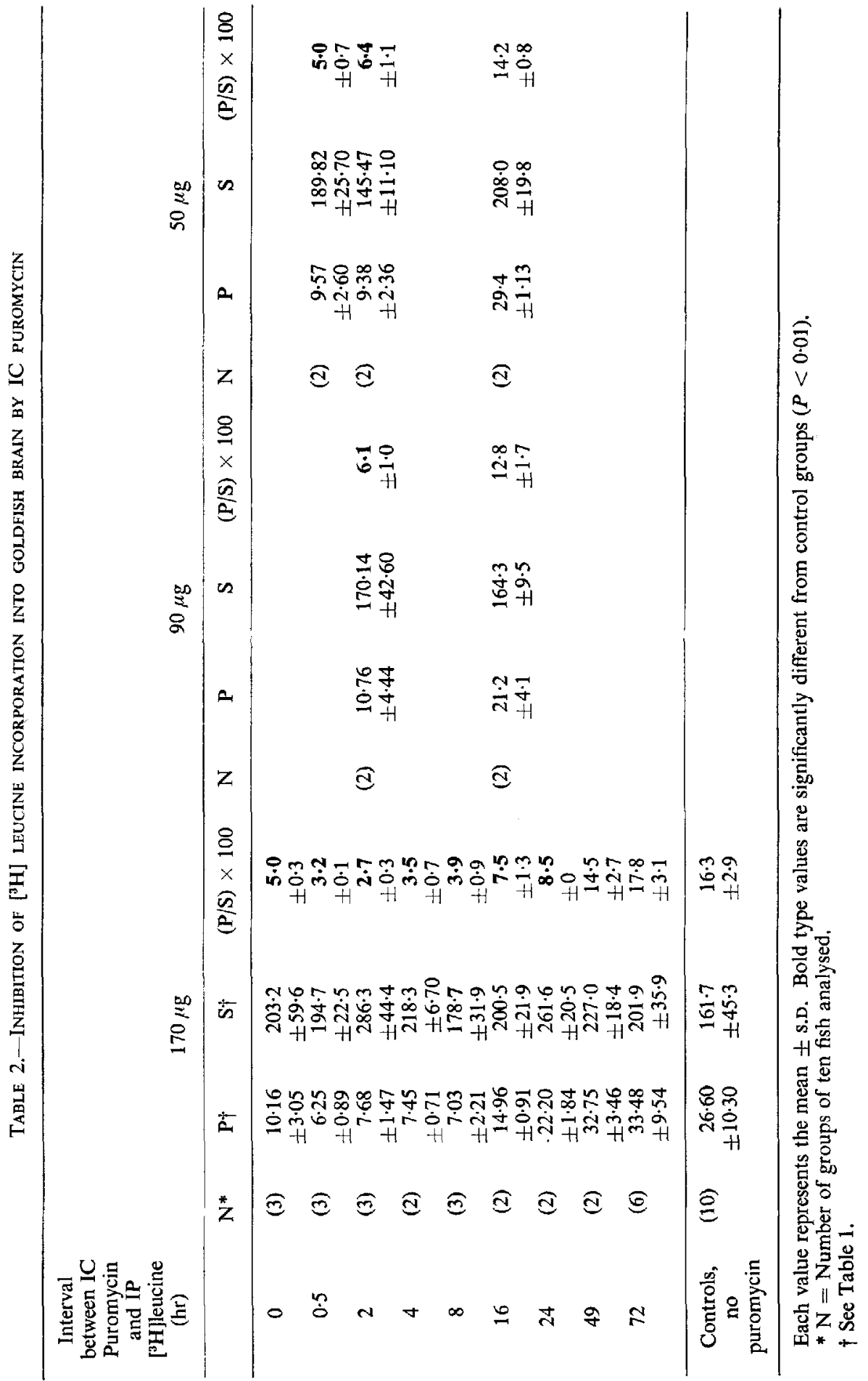




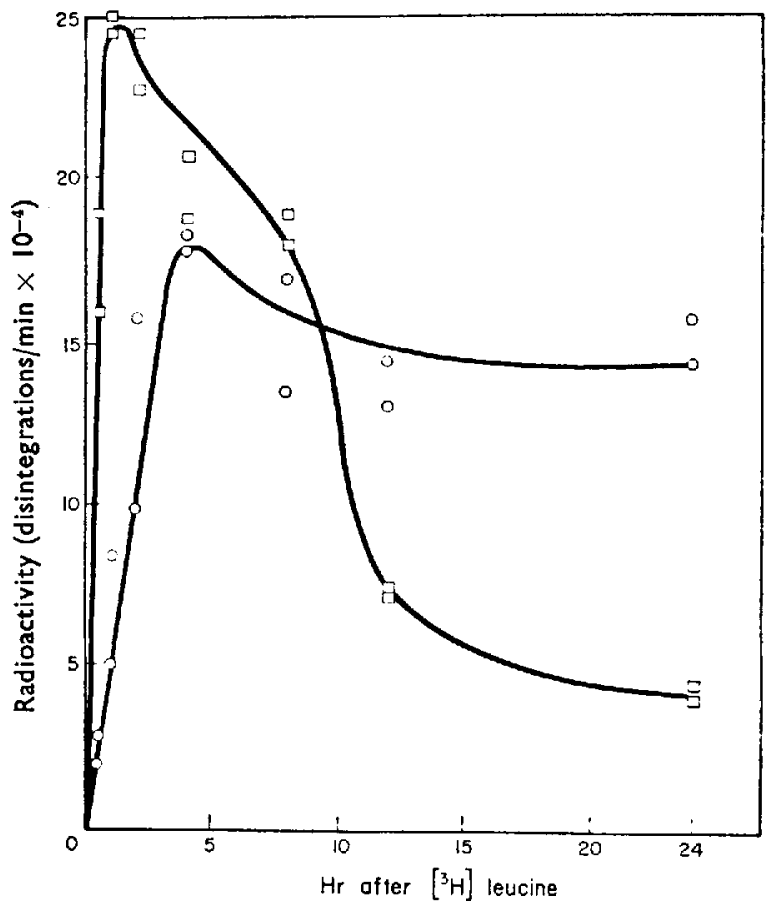

FIG. 1.-Radioactivity in trichloroacetic acid-soluble $\square$ and insoluble $\bigcirc$ fractions of goldfish brain at various times following IP injection of $20 \mu \mathrm{C}$ of $\left[{ }^{3} \mathrm{H}\right]$ leucine. Two groups of five fish were analysed for each time studied. Results are expressed as disintegrations/min/fish.

TABLE 3.- INHIBITION OF $\left[{ }^{3} \mathrm{H}\right]$ LEUCINE INCORPORATION INTO GOLDFISH BRAIN PROTEIN BY $0.1 \mu \mathrm{g}$ ACETOXYCYCLOHEXIMIDE INJECTED IC

\begin{tabular}{|c|c|c|c|c|}
\hline $\begin{array}{l}\text { Interval } \\
\text { between IC } \\
\text { AXM and IP } \\
{\left[{ }^{3} \mathrm{H}\right] \text { leucine (hr) }}\end{array}$ & $N^{*}$ & $\mathrm{P}+$ & $\mathbf{S} \dagger$ & $(\mathrm{P} / \mathrm{S}) \times 100$ \\
\hline Control $\$$ & & & & $16 \cdot 3$ \\
\hline 0.5 & (2) & $9 \cdot 6 \div 2 \cdot 0$ & $198 \pm 14.0$ & $4.9 \pm 0.7$ \\
\hline 2 & (2) & $3.5 \pm 0.28$ & $125.4 \pm 0.47$ & $2 \cdot 8 \pm 0 \cdot 3$ \\
\hline 8 & (2) & $4.4 \pm 0.45$ & $163.7 \pm 19.9$ & $2.7 \pm 0.1$ \\
\hline 24 & (2) & $12 \cdot 3 \pm 3 \cdot 8$ & $175.6 \pm 66.3$ & $7.2 \pm 0.6$ \\
\hline 72 & (2) & $10.7 \pm 3.8$ & $119.6 \pm 8.45$ & $8.9 \pm 2.5$ \\
\hline
\end{tabular}

$* \dagger \pm$ See Table 2 .

AXM. Experiments similar to those described with puromycin were performed except that $0.1 \mu \mathrm{g}$ of AXM was administered. The onset of inhibition of protein synthesis and the extent of inhibition (Table 3) were similar to these produced by $170 \mu \mathrm{g}$ of puromycin. However, the inhibition by AXM persisted much longer.

Actinomycin D. In contrast to puromycin and AXM, an injection of $2 \mu \mathrm{g}$ of actinomycin D inhibited protein synthesis slowly (Table 4). The level of inhibition at $24 \mathrm{hr}$ was similar to that seen with puromycin and AXM at $2 \mathrm{hr}$. Extensive inhibition persisted for more than 3 days. During the $72 \mathrm{hr}$ experimental period, none of the 
fish died. Behavioural studies in this laboratory suggested, however, that this dose produced some degree of illness. When $10 \mu \mathrm{g}$ of actinomycin D were injected IC, all of the fish died within $60 \mathrm{hr}$.

Influence of drug concentration on the inhibition of protein synthesis by $\mathrm{AXM}$ and puromycin. The relative effectiveness of puromycin and AXM in blocking brain protein synthesis was studied in fish that had received different doses of the two drugs. At $1 \mathrm{hr}$ after receiving either drug IC, fish were given $20 \mu \mathrm{C}$ of $\left[{ }^{3} \mathrm{H}\right]$ leucine IP and killed $30 \mathrm{~min}$ later. Inhibition of protein synthesis by the two drugs was expressed as a percentage of the ratio obtained for untreated control fish. The results in Fig. 2 show that AXM was much more effective in depressing protein synthesis than was puromycin. To attain 50 per cent inhibition, a 400 - to 500 -fold molar excess of puromycin to AXM was required.

TABLE 4.-INHIBITION OF [3] ${ }^{3}$ LEUCINE INCORPORATION INTO GOLDFISH BRAIN PROTEIN BY $2 \mu \mathrm{g}$ OF ACTINOMYCIN D INJECTED IC

\begin{tabular}{|c|c|c|c|c|}
\hline $\begin{array}{l}\text { Interval } \\
\text { between IC } \\
\text { actinomycin } \\
\text { and IP } \\
{\left[{ }^{3} \mathrm{H}\right] \text { leucine (hr) }}\end{array}$ & $\mathrm{N}^{*}$ & $\mathrm{P} \dagger$ & $S \dagger$ & $(\mathrm{P} / \mathrm{S}) \times 100$ \\
\hline $\begin{array}{l}\text { Control }+ \\
2 \\
8 \\
24 \\
72\end{array}$ & $\begin{array}{l}(2) \\
(2) \\
(2) \\
(2)\end{array}$ & $\begin{array}{r}23 \cdot 1 \pm 4 \cdot 17 \\
14 \cdot 2 \pm 6 \cdot 93 \\
4 \cdot 74 \pm 4 \cdot 4 \\
10 \cdot 98 \pm 4 \cdot 1\end{array}$ & $\begin{array}{l}156 \cdot 5 \pm 13 \cdot 3 \\
136 \cdot 0 \pm 45 \cdot 6 \\
123 \cdot 4 \pm 108 \cdot 0 \\
164.8 \pm 29 \cdot 2\end{array}$ & $\begin{array}{c}16 \cdot 3 \\
14.7 \pm 1.4 \\
10.2 \pm 1.7 \\
3.7 \pm 0.3 \\
6.6 \pm 1.4\end{array}$ \\
\hline
\end{tabular}

$* \dagger+$ See Table 2 .

\section{DISCUSSION}

The present experiments confirm our preliminary findings (AGRANOFF, DAvIS and BRINK, 1965) that the extent and duration of inhibition of $\left[{ }^{3} \mathrm{H}\right]$ leucine incorporation into protein varies with the dose of puromycin administered. Expression of the results as a ratio of radioactivities rather than as specific activities produces more consistent estimates of the inhibitory effects of drugs. Variability in the injection site, the size of the brain, and of body pools, as well as the amount of leucine injected are minimized by the use of this ratio, which indicates how much of the labelled leucine entering the brain is incorporated into protein. When [ $\left.{ }^{3} \mathrm{H}\right]$ leucine is administered IP, 0.6 per cent of the injected radioactivity is found in the brain $1 \mathrm{hr}$ later. The time course (Fig. 1) indicates a complex turnover involving at least two decay constants in the soluble fraction since a shoulder is seen. About 0.4 per cent of the injected dose appears in the trichloroacetic acid-precipitable fraction in about $4 \mathrm{hr}$. The level of radioactivity remains elevated after a slight initial decline. Sufficiently long times following puromycin to observe further loss of radioactivity were not examined. It is possible that the prolonged decay represents stable protein, or a slow equilibration with body pools of leucine outside of the brain. An apparent but not significant rise in the radioactivity in the trichloroacetic acid supernatant fraction $2 \mathrm{hr}$ following a puromycin injection, resembling other reported increases (FLEXNER, FLEXNER, RoBERTS and DE LA HABA, 1964) is compensated for in our calculations of the degree of protein inhibition. FLEXNER, FLEXNER and STELLAR (1963) reported that intracerebral injections of puromycin can obliterate memory of maze training in mice when protein synthesis 


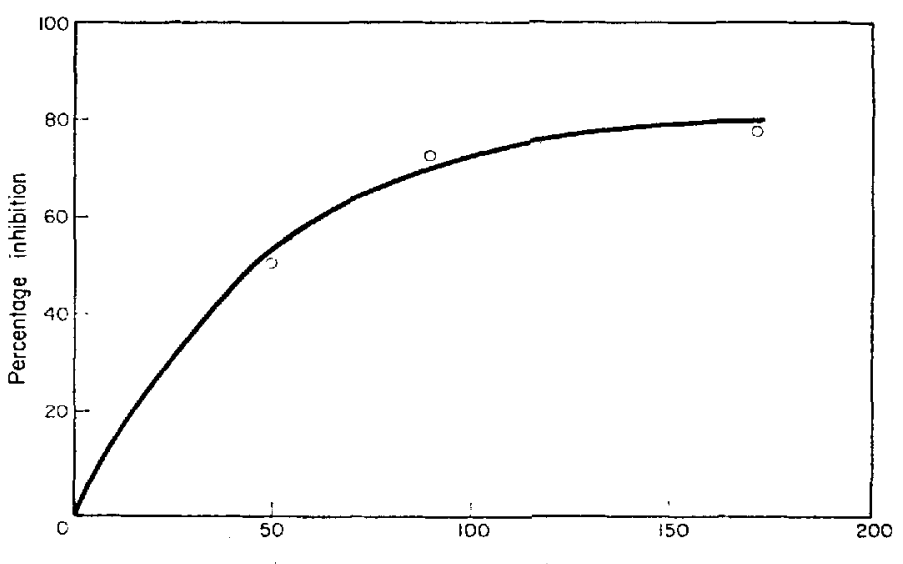

$\mu \mathrm{g}$ of puromycin

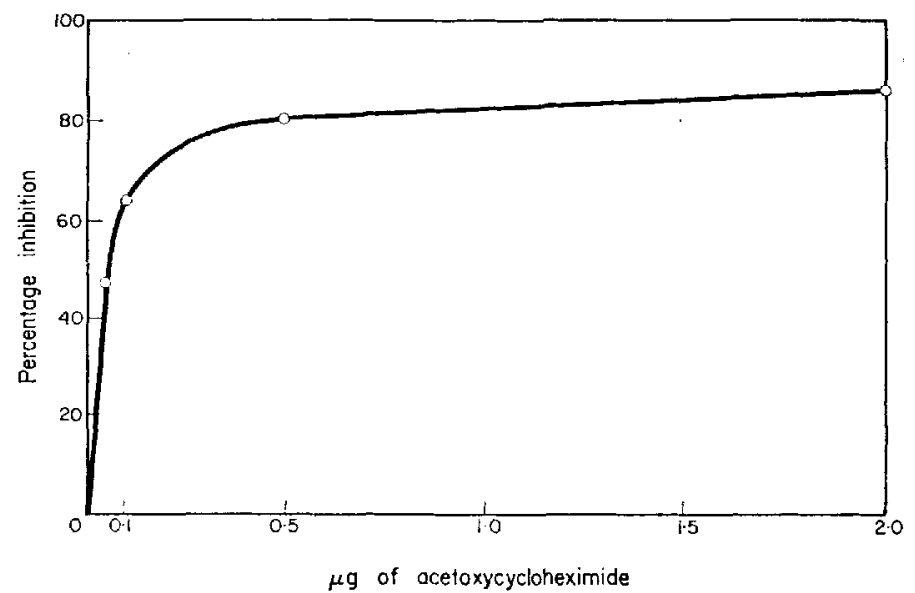

FIG. 2.-Inhibition of $\left[{ }^{3} \mathrm{H}\right]$ leucine incorporation into goldfish brain protein by puromycin and AXM. Drugs were injected at various concentrations $1 \mathrm{hr}$ before $\left[{ }^{3} \mathrm{H}\right]$ leucine was injected IP. Animals were killed 30 min later. Percentage inhibition is calculated from the ratios of $(\mathbf{P} / \mathrm{S}) \times 100$ of experimental groups compared to control groups.

in bilateral temporal injection sites is reduced by 80 per cent for $8-10 \mathrm{hr}$. Behavioural experiments with subcutaneously injected puromycin or chloramphenicol did not produce a memory deficit (Flexner, Flexner, Stellar, de la HaBa and Roberts, 1962; FLeXNeR et al., 1964). This was attributed to a less effective inhibition of protein synthesis than could be obtained following intracerebral injections of puromycin.

In goldfish, IC injection of $170 \mu \mathrm{g}$ puromycin results in $80-90$ per cent inhibition of protein synthesis for $2-8 \mathrm{hr}$ following injection. Behavioural experiments have shown that this dose loses half of its effect on memory within $2 \mathrm{hr}$, while $90 \mu \mathrm{g}$ of puromycin loses all of its effect on memory within the same interval. Both 90 and $170 \mu \mathrm{g}$ of puromycin interfere with memory when injected within $1 \mathrm{hr}$ after trials, but $50 \mu \mathrm{g}$ do not (AGRANOFF et al., 1965). 
The inhibition seen at $2 \mathrm{hr}$ and $16 \mathrm{hr}$ following the $50 \mu \mathrm{g}$ injection is similar to that seen with $90 \mu \mathrm{g}$, although preliminary investigations indicate differences in protein inhibition for intervening time points (AGRANOFF et al., 1965). These results could mean that some metabolic process involved in memory fixation is secondary to the process blocked by protein synthesis and recovers before leucine incorporation returns to the normal level. Since we measure total brain protein, the inhibition curve of specific proteins involved in the fixation process may be occluded. Protein synthesis in a specific locus in the brain which corresponds more closely to the timing of the behavioural effect as suggested by FLEXNER et al. (1964) would also be masked in the whole brain analyses. If a specific anatomical site is involved, it appears to be rapidly accessible to puromycin.

The proposed mechanism for the depression of protein synthesis by puromycin relates the similarity in structure of puromycin to the aminoacyladenosine terminus of activated transfer RNA (YARMOLINSKY and DE LA HABA, 1959). Puromycin can be attached to the nascent peptide to form peptidyl puromycin which is released from the ribosome (Morris, Favelukes, Arlinghaus and Schweet, 1962; Nathans and Neidle, 1963; Nathans, 1964).

To investigate further the possibility that protein synthesis is related to memory we sought an inhibitor unrelated in structure to puromycin, and known to be effective in vivo in animals. The most potent such agent presently known is AXM (YounG, RoBINSON and SACKTOR, 1965). A model for its mode of action can be inferred from the study of Trakatellis, Montuar and Axelrod (1965) who showed that cycloheximide (a closely related compound) can prevent the transfer of activated amino acids to polypeptides and their subsequent release from polysomes. AXM is a powerful inhibitor of brain protein synthesis (Table 3 and Fig. 2). AXM also affects memory in goldfish (AGRANOFF et al., 1966), although its action on memory disruption may not be as marked as that of puromycin.

It was not possible to inhibit brain protein synthesis by more than $80-90$ per cent even with relatively large doses of AXM. The residual 10-20 per cent of protein synthesis that takes place may reside in areas of the brain that are not readily accessible to either drug, or may represent a form of leucine incorporation that is unrelated to the effects of these drugs. For example, it was found (CAMPBEll, MaHler, Moore and TEWARI 1966) that mitochondrial protein synthesis in rat brain is insensitive to ribonuclease.

The effects of actinomycin D are well documented (ReICH, Franklin, Shatkin and TATUM, 1962). The major reported effect of this compound is to block DNAdependent formation of RNA. Recent evidence has shown that in various mammalian cells it may also (a) accelerate messenger RNA destruction (HARRIS, 1964) (b) block protein synthesis directly or by a block which can be abolished by increasing glucose levels (HoNig and RaBinovitz, 1965) and $(c)$ produce a combination of irreversible changes which ultimately lead to the death of the animal. Behavioural experiments on fish in our laboratory with actinomycin were complicated by decrements in performance which were independent of the time of injection. Hence a distinction between toxic effects unrelated to memory and a specific memory block was not possible. Studies on the effects of intracerebrally injected actinomycin D on memory in mice by BARONDES and JARVIK (1964) indicated no effect on memory or learning under conditions in which brain RNA synthesis was inhibited 80 per cent. 


\section{SUMMARY}

Intraperitoneally injected $\left[{ }^{3} \mathrm{H}\right]$ leucine is incorporated into goldfish brain protein, the maximum being reached in $4 \mathrm{hr}$.

When puromycin or acetoxycycloheximide is injected intracranially, there is a rapid onset of inhibition of incorporation of labelled leucine which lasts for days.

The inhibitory effect of actinomycin D on protein synthesis occurs more slowly, and becomes maximal a day after injection.

\section{REFERENCES}

Agranoff B. W. and Klinger P. D. (1964) Science 146, 952.

Agranoff B. W., Davis R. E. and BrinK J. J. (1965) Proc. nat. Acad. Sci. (Wash.) 54, 788.

Agranoff B. W., Davis R. E. and Brink J. J. (1966) Brain Res. 1, 303.

Barondes S. H. and JARVIK M. E. (1964) J. Neurochem. 11, 187.

Bruno G. A. and Christian J. E. (1961) Analyt. Chem. 33, 1216.

Campbell M. K., Mahler H. R., Moore W. J. and Tewari S. (1966) Biochemistry, 5, 1174.

Davis R. E., Bright P. J. and Agranoff B. W. (1965) J. comp. Physiol. Psychol, 60, 162.

Flexner L. B., Flexner J. B., RoberTs R. B. and DE LA HABA G. (1964) Proc. nat. Acad. Sci. (Wash.) 52,1165 .

Flexner J. B., Flexner L. B. and Stellar E. (1963) Science 141, 57.

FlexNer J. B., FlexNer L. B., Stellar E., De la Haba G. and Roberts R. B. (1962) J. Neurochem. 9, 595.

HARRIS H. (1964) Nature, Lond. 202, 1301.

HonIG G. R. and Rabinovitz M. (1965) Science 149, 1504.

LeVtNe L. and Musallam D. A. (1964) Experienta 20, 508.

Morris A., Favelukes S., Arlinghaus R. and Schweet R. (1962) Biochem. Biophys. Res. Comm. $7,326$.

Nathans D. (1964) Proc. nat. Acad. Sci. (Wash.) 51, 585.

Nathans D. and NeIDle A. (1963) Nature, Lond. 197, 1076.

Reich E., Franklin R. M., Shatkin A. J. and Tatum E. L. (1962) Proc. nat. Acad. Sci. (Wash.) 48,1238 .

RoBerts S. and Morelos B. W. (1965) J. Neurochem. 12, 373.

Trakatellis A. C., MontJar M. and AXelrod A. E. (1965) Biochemistry 4, 2065.

Yarmolinsky M. B. and de la Haba G. L. (1959) Proc, nat. Acad. Sci. (Wash.) 45, 1721.

Young C. W., RoBinson P. F. and SACKTOR B. (1965) Biochem. Pharmacol. 12, 855. 